No circulatory or metabolic changes were found which might account for the severity of symptoms in accidental hypothermia in persons who have walked to the point of exhaustion. Blood volume normally falls by 5 to $15 \%$ during the first 10 to 15 minutes of muscular exercise (for references see Pugh, 1969), and we had expected to find a further decrease in blood volume associated with exhaustion in hill-walkers. This, however, appears not to be the case, at any rate in persons who have free access to fluid and take occasional short rests. According to recent catheter studies (Ekelund, 1967), the rising heart rate and tendency to postural hypotension in persons working to exhaustion are due essentially to failure of vasomotor regulation and not to changes in blood volume. They found reduced cardiac stroke output, reduced peripheral resistance, and altered distribution of blood in the capacitance vessels.

The only positive observation bearing on fatigue was ketonuria. Subject S. H., who finished in a state of partial collapse on Edale I, showed the greatest degree of ketonuria, and there was less ketonuria on Edale II, when the subjects seemed less tired. Two months later urine samples were collected on 250 participants in a $50-$ mile $(80-\mathrm{km}$.) walking competition in the same area. The leading teams that completed the course at a run showed no ketonuria. Slower teams showed ketonuria roughly in proportion to their times. Some participants who were exhausted showed obvious mental changes in spite of the fact that the competition took place in warm weather. This was an important observation, since mental change is a common early finding in " exposure" accidents, and is usually attributed to hypothermia.

Those taking part in the investigation were Dr. K. E. Cooper and Dr. R. Johnson of the Medical Research Council Body Temperature Research Unit ; Dr. Mary Lobban, Miss Pamela Dean, and Mr. J. A. Crisp of the Division of Human Physiology, National Institute for Medical Research ; Dr. E. S. N. Fenton, Dr. G. Ll. Glynne, Dr. P. J. Andrew, and Mr. A. Edgeson of Electronics Instruments Ltd. The electrolyte and sugar determinations were done at the Biochemistry Department, the Radcliffe Infirmary, Oxford. The Rover Scouts acting as subjects were: R. McBlane,
M. G. Crome, S. S. Hatton, B. T. Hunt, R. A. Rogerson, B. Nicholson, and their team leader D. Crowley. Metabolic measurements were made on Mr. J. Cooper. The help and collaboration of all concerned is gratefully acknowledged. The research was supported by a grant from the Royal College of Surgeons' Accident Prevention Commission.

\section{REFERENCES}

Alexander, L. (1946). Publication Board Report No. 250. Washington, D.C., Department of Commerce.

Belding, H. S. (1949). In Physiology of Heat Regulation and the Science of Clothing, edited by L. H. Newburgh, p. 351. Philadelphia, Saunders.

Belding, H. S., Russell, H. D., Darling, R. C., and Folk, G. E. (1947), American fournal of Physiology, 149, 223

Burton, A. C. (1935). Fournal of Nutrition, 9, 261.

Burton, A., and Edholm, O. G. E. (1955). Man in a Cold Environment. London, Arnold.

Cooper, K. E., Hunter, A. R., and Keatinge, W. R. (1964). International Anesthesiology Clinics, 2, 999.

Edwards, D. A. W., Hammond, W. H., Healey, M. J. R., Tanner, J. M., and Whitehouse, R. H. (1955). British fournal of Nutrition, 9, 133. Ekslund, L-G. (1967). Acta Physiologica Scandinarica, 70, Suppl. No.

Fox, R. H., Goldsmith, R. H., and Wolff, H. S. (1962). fournal of Physiology, 160, 22P

Hardy, J. D. (1949). In Physiology of Heat Resulation and the Science of Clothing, edited by L. H. Newburgh, p. 78. Philadelphia, Saunders.

Lundgren, N. P. V. (1946). Acta Physiologica Scandinavica, 13, Suppl. No. 41, p. 105 .

Nielsen, M. (1938). Skandinavisches Archiv fïr Physiologie, 79, 193.

Pugh, L. G. C. E. (1949). Report prepared for the Climatic Eficiency Sub-Committee of the Royal Naval Personnel Research Committee. (R.N.P. 49/561, C.E.S. 306.)

Pugh, L. G. C. E. (1964a). Fournal of Physiology, 170, 344.

Pugh, L. G. C. E. (1964b). Lancet, 1, 1210.

Pugh, L. G. C. E. (1964b). Lancet, 1, 1210 .

Pugh, L. G. C. E. (1966a). British Medical fournd

Pugh, L. G. C. E. (1966b). Nature, 209, 1281.

Pugh, L. G. C. E. (1967). British Medical Fournal, 2, 333

Pugh, L. G. C. E. (1969). Fournal of Fhysiology. In press.

Robinson, S. (1949). In Physiology of Heat Regulation and the Science of Clothing, edited by L. H. Newburgh, p. 193. Philadelphia, Saunders.

Robinson, S. (1963). Pediatrics, 32, 691.

Saltin, B. (1964). Acta Physiologica Scandinavica, 62, Suppl. No. 230,

Sipple, P. (1945). In Clothing Test Methods, edited by L. H. Newburgh and Milton Harris, p. 65. Washington, D.C., National Research

Wolf. H. S. (1958). Quarterly fosirnal of Experimental Physiology, 43,

Wyndham, C. H. (1965). Fournal of Applied Physiology, 20, 31.

\title{
Vincristine and Prednisone for the Induction of Remissions in Acute Childhood Leukaemia
}

\author{
R. M. HARDISTY,* M.D., M.R.C.P., F.C.PATH. ; T. J. MCELWAIN, $\dagger$ M.B., M.R.C.P. \\ CARYL W. DARBY, M.B., M.R.C.P.
}

ummary : A total of 65 children with acute lympho-
blastic leukaemia and seven with other types of
acute leukaemia received treatment with a combination of
vincristine and prednisone. In all 122 courses of treat-
ment were given. Of 22 patients with acute lymphoblastic
leukaemia who received this as their first treatment, all
achieved complete remission. The complete remission
rates were $82 \%$ for patients with acute lymphoblastic
leukaemia in their first relapse, $63 \%$ in the second
relapse, and much lower in subsequent relapses and in
the patients with other types of acute leukaemia.
Alopecia and gastrointestinal and neuromuscular toxicity
occurred respectively in $51 \%, 29 \%$ and $21 \%$ of instances, only the last of these side-effects of vincristine being doserelated. Most of the complete remissions were obtained with a total dose of vincristine which carried only a low risk of neurotoxicity.

\section{Introduction}

It is now well established that combinations of certain antileukaemic drugs are superior to the same drugs used singly for

\footnotetext{
* Professor of Haematology.

† Leukaemia Research Fellow.

Department of Haematology, Institute of Child Health, the Hospital for Sick Children, Great Ormond Street, London W.C.1.
} 
the induction of remissions in acute leukaemia (Acute Leukemia Group B, 1965 ; Frei et al., 1965; Krivit et al., 1966 ; Karon, 1968). Vincristine sulphate (Oncovin), for example, is now generally accepted as a valuable remissioninducing agent in acute lymphoblastic leukaemia, both at the onset of the disease and during relapse (Karon et al., 1962; Evans et al., 1963 ; Heyn et al., 1965 ; Karon et al., 1966 ; Howard, 1967 ; Haggard et al., 1968), but its effectiveness has been shown to be greatly enhanced by combination with prednisone, when remission rates of over $80 \%$ can be achieved (Acute Leukemia Group B, 1965 ; Hananian et al., 1965). It is less useful as a maintenance agent, both on account of its cumulative toxicity and because the length of remissions maintained with vincristine compares unfavourably with those maintained with other agents (Karon et al., 1966 ; Haggard et al., 1968).

Many of the previously reported results of treatment with vincristine have referred to groups of patients treated at various stages of their disease. In this paper we analyse our experience with vincristine and prednisone as a remission-inducing combination in previously untreated acute lymphoblastic leukaemia in children, and show that the results compare favourably with those of other reported regimens, including, for example, the triple therapy with prednisone, vincristine, and Rubidomycin described by Mathé et al. (1967). We also show that the efficacy of this combination diminishes progressively with succeeding relapses, and that neurotoxicity can be largely avoided by confining the dose of vincristine to the minimum necessary to induce remission. No evidence is presented on the effect of vincristine and prednisone on the duration of remissions, as these were all subsequently maintained by the use of other drugs.

\section{Patients}

During the past four years 65 patients with acute lymphoblastic leukaemia, aged 10 months to 11 years, and seven with other types of acute leukaemia, aged 3 to 12 years (Table I) have received a total of 122 courses of treatment with vincristine and prednisone at the Hospital for Sick Children. Of the lymphoblastic group 31 patients have received a single course so far, 22 have received two courses each, 10 have received three, and two have received four separate courses.

\begin{tabular}{|c|c|c|c|c|}
\hline \multicolumn{3}{|c|}{$\begin{array}{c}\text { Type of Acute } \\
\text { Leukaemia }\end{array}$} & $\begin{array}{l}\text { No. of } \\
\text { Patients }\end{array}$ & $\begin{array}{l}\text { No. of Courses of } \\
\text { Treatment }\end{array}$ \\
\hline $\begin{array}{l}\text { Lymphoblastic } \\
\text { Myeloblastic } \\
\text { Myelomonocytic } \\
\text { Plasma cell ... }\end{array}$ & $\begin{array}{l}\ldots \\
\therefore \\
\therefore\end{array}$ & $\begin{array}{l}\ldots \\
\cdots \\
\cdots\end{array}$ & $\begin{array}{r}65 \\
5 \\
1 \\
1\end{array}$ & $\begin{array}{r}113 \\
6 \\
1 \\
2\end{array}$ \\
\hline
\end{tabular}

\section{Dosage}

Prednisone was given to all patients at about $60 \mathrm{mg}$. per sq. $m$. body surface per day, in divided dosage, for two to four weeks, and then tailed off over about another 10 to 14 days in most instances. Vincristine was given intravenously weekly: individual doses varied from 1 to $3.3 \mathrm{mg}$./sq. m., but were within the range of $1.5-2.0 \mathrm{mg} . / \mathrm{sq} . \mathrm{m}$. in $80 \%$ of instances. Up to seven weekly doses were given, but $90 \%$ of courses consisted of two to four doses of vincristine. Patients received supportive therapy with red cell and platelet transfusions, and with antibiotics whenever this was indicated.

\section{Criteria of Remission}

Patients were considered to be in complete remission when bone-marrow smears showed not more than $5 \%$ of blasts in a cellular marrow, when the peripheral blood contained no leukaemic cells and not less than 1,500 neutrophils and 100,000 platelets per cu. mm., and when there was no clinical evidence of enlargement of liver, spleen, or lymph nodes, or of infiltration of other organs-for example, kidneys or gonads. Evidence of meningeal leukaemia was not held to disqualify from complete-remission status, since this complication occurs independently of the state of the leukaemia in other sites, and is not amenable to most forms of systemic therapy. In fact none of the patients had evidence of meningeal involvement at the time of achieving complete remission, though 10 had such evidence at the time of haematological relapse (one during two relapses) and were therefore treated with intrathecal methotrexate concurrently with the vincristine and prednisone.

Patients showing significant clinical and haematological improvement (diminution in organ size and marked reduction in total peripheral blood and/or marrow blast cell count, with symptomatic improvement), but without reversion to completeremission status (see above), were considered to have achieved partial remission.

\section{Results}

In Table II the results in acute lymphoblastic leukaemia are subdivided into those achieved in previously untreated patients at the time of diagnosis and those achieved in subsequent relapses. The small number of other types of acute leukaemia are considered as a single group, irrespective of the stage of disease at which the treatment was given; three of these were treated at diagnosis, two in the first, three in the second, and one in the third relapse.

\begin{tabular}{|c|c|c|c|c|c|c|}
\hline \multirow{3}{*}{$\begin{array}{c}\text { Type } \\
\text { of } \\
\text { Leukaemia }\end{array}$} & \multirow{3}{*}{$\begin{array}{c}\text { Stage } \\
\text { of } \\
\text { Disease }\end{array}$} & \multirow{3}{*}{$\begin{array}{l}\text { Total } \\
\text { Courses } \\
\text { of } \\
\text { Treat- } \\
\text { ment }\end{array}$} & \multicolumn{4}{|c|}{ Remissions } \\
\hline & & & \multicolumn{2}{|c|}{ Complete } & \multicolumn{2}{|c|}{ Complete + Partia } \\
\hline & & & No. & $\%_{0}$ & No. & $\%$ \\
\hline $\begin{array}{l}\text { Acute } \\
\text { lympho- } \\
\text { blastic }\end{array}$ & $\begin{array}{l}\text { Initial treatment } \\
\text { 1st relapse } \\
\text { 2nd relapse } \\
\text { 3rd relapse } \\
\text { 4th-6th relapse }\end{array}$ & $\begin{array}{l}22 \\
22 \\
30 \\
24 \\
15\end{array}$ & $\begin{array}{r}22 \\
18 \\
19 \\
6 \\
1\end{array}$ & $\begin{array}{r}100 \\
82 \\
63 \\
25 \\
6\end{array}$ & $\begin{array}{l}22 \\
18 \\
27 \\
13 \\
5\end{array}$ & $\begin{array}{r}100 \\
82 \\
90 \\
54 \\
33\end{array}$ \\
\hline Other acute & All stages & 9 & 1 & 11 & 5 & 56 \\
\hline \multicolumn{2}{|c|}{ Totals } & 122 & 67 & 55 & 90 & 74 \\
\hline
\end{tabular}

In 22 consecutive patients with acute lymphoblastic leukaemia who reccived vincristine and prednisone as their first treatment we have so far had no failure to achieve complete remission with this regimen, and all but two of these results were achieved within four weeks of starting treatment. The lower $95 \%$ confidence limit of an observed $100 \%$ remission rate in a series of this size is $87 \%$, and the $99 \%$ confidence limit is $81 \%$.

There was a slight diminution in complete remission rate at the first relapse, and again at the second relapse, and a much poorer response in patients in third or subsequent relapses. The time from diagnosis of acute lymphoblastic leukaemia to first, second, third, and subsequent relapses in this series is indicated in Table III. Since onty 8 of the 39 courses given for third or subsequent relapses were the first the patient had received, and since there were only seven failures and eight partial remissions among the 52 courses given for first and second relapses, whether or not the patient had previously received vincristine and prednisone, it was not possible in this series to determine whether the diminishing probability of response with successive relapses was chiefly attributable to the development of acquired resistance to the drugs or whether it was an inherent function of the stage of advancement of the disease. Of the 34 patients with acute lymphoblastic leukaemia who have received more than one course, 18 have achieved two remissions (six of these patients are still alive in the second of these, and will eventually receive a third course), four have 
achieved three remissions each, and one has achieved four successive complete remissions on this treatment.

\begin{tabular}{|c|c|c|c|}
\hline \multirow{2}{*}{ Relapse No. } & \multicolumn{3}{|c|}{ Time Since Diagnosis of Leukaemia (Weeks) } \\
\hline & Mean & Median & Range \\
\hline $\begin{array}{c}1 \\
2 \\
3 \\
4-6 \text { inclusive }\end{array}$ & $\begin{array}{l}44 \\
74 \\
86 \\
97\end{array}$ & $\begin{array}{l}31 \\
61 \\
69 \\
87\end{array}$ & $\begin{array}{r}7-218 \\
17-257 \\
28-264 \\
52-174\end{array}$ \\
\hline
\end{tabular}

\section{Vincristine Dosage}

The total number of weekly doses of vincristine in each course of treatment is shown separately in Table IV for those cases in which complete remission was achieved and for the remainder. In three-quarters of all courses, three or four weekly doses were used and in only 2 out of the 69 instances in which complete remission was achieved were more than four doses required.

\section{TABLE IV.-Total Number of Weekly Doses of Vincristine}

\begin{tabular}{l|ll|l|l|l|l|c} 
& \multicolumn{8}{c}{ Doses of Vincristine } \\
\cline { 2 - 7 } & 1 & 2 & 3 & 4 & 5 & 6 & $>6$ \\
\hline $\begin{array}{l}\text { Complete remissions } \\
\text { Partial remissions and failures }\end{array}$ & 0 & 8 & 42 & 17 & 2 & 0 & 0 \\
& & 9 & 15 & 18 & 4 & 6 & 1
\end{tabular}

The total dose of vincristine given during each course, in relation to body surface area, is shown in Table V. In the whole series the total dose ranged from 3 to $14 \mathrm{mg}$./sq. m., and $62 \%$ of the courses $(76 / 122)$ totalled $6 \mathrm{mg}$. $/ \mathrm{sq}$. m. or less. Three-quarters of the complete remissions $(52 / 59)$ fell into this low-dose group; the only complete remission requiring more than $10 \mathrm{mg}$./sq. m. was achieved in a 12-year-old boy with acute plasma-cell leukaemia, at the onset of his disease.

TABLE V.-Total Dose of Vincristine

\begin{tabular}{|c|c|c|c|c|c|c|c|}
\hline \multirow[t]{2}{*}{. } & \multicolumn{7}{|c|}{ Total Vincristine (mg./sq.m.) } \\
\hline & & $2-$ & $4-$ & $6-$ & $8-$ & $10-$ & $12-$ \\
\hline $\begin{array}{l}\text { Complete remissions } . \dot{\text { failures }} \\
\text { Partial remissions and }\end{array}$ & $\begin{array}{l}\ldots \\
\cdots\end{array}$ & $\begin{array}{l}8 \\
8\end{array}$ & $\begin{array}{l}44 \\
16\end{array}$ & $\begin{array}{l}11 \\
15\end{array}$ & $\begin{array}{l}4 \\
5\end{array}$ & $\begin{array}{l}2 \\
8\end{array}$ & $\begin{array}{l}0 \\
1\end{array}$ \\
\hline
\end{tabular}

\section{Vincristine Toxicity}

The incidence of the three chief types of side-effect of vincristine in this series in relation to the total dose administered in individual courses is shown in Table VI. Bulkproducing laxatives were used routinely to prevent constipation and intestinal colic so far as possible. It is obvious from Table VI that the incidence of alopecia was not doserelated, and that of gastrointestinal toxicity was at least not significantly so in this series. Neuromuscular toxicity, on the other hand, is clearly dose-related. It should be stressed, however, that the figures in Table VI relate solely to symptoms of toxicity; loss of deep tendon reflexes alone, for example, or minor degrees of muscular weakness detected on examination but unnoticed by the patient or his parents, have not been included, as such findings are reversible and of little clinical significance. Among the neuromuscular symptoms observed were pains in the jaw and limbs, ptosis, foot-drop, weakness of limbs, and (in three cases) generalized convulsions without apparent alternative cause. Most of these, including all those which developed in the lowest dosage group, were only transitory.

Table VI also shows that most of the complete remissions were achieved with a dose of vincristine which carried a low risk of neurotoxicity. In general it would seem fair to conclude from these figures that if remission has not occurred before serious' neurotoxic effects are seen it is unlikely to be achieved if further doses of vincristine are given.

\begin{tabular}{|c|c|c|c|c|c|}
\hline \multirow{2}{*}{$\begin{array}{l}\text { Total } \\
\text { Dose } \\
\text { (mg.l } \\
\text { sq.m.) }\end{array}$} & \multirow{2}{*}{$\begin{array}{l}\text { No. of } \\
\text { Courses }\end{array}$} & \multirow{2}{*}{$\begin{array}{c}\text { Complete } \\
\text { Remissions }\end{array}$} & \multicolumn{3}{|c|}{ Symptoms of Toxicity } \\
\hline & & & Alopecia & $\begin{array}{c}\text { Gastro- } \\
\text { intestinal* }\end{array}$ & $\begin{array}{c}\text { Neuro- } \\
\text { musculart }\end{array}$ \\
\hline $\begin{array}{c}>\overrightarrow{6} \rightarrow 10 \\
>10 \\
\end{array}$ & $\begin{array}{l}70 \\
34 \\
11 \\
\end{array}$ & $\begin{array}{c}48(69) \\
14(41) \\
1(9) \\
\end{array}$ & $\begin{array}{r}34(49) \\
19(56) \\
6(55) \\
\end{array}$ & $\begin{array}{r}19(27) \\
9(26) \\
5(46) \\
\end{array}$ & $\begin{array}{r}9(13) \\
10(29) \\
5(46)\end{array}$ \\
\hline All courses & 115 & $63(55)$ & $59(51)$ & $33(29)$ & $24(21)$ \\
\hline
\end{tabular}

Percentage remission rate and toxicity for each dosage group shcwn in parentheses. Seven courses have been excluded from this analysis, as follow-up was not long
enough for assessment of toxicity.

Significance of dose relationship:

* $\chi^{2}$ (2 d.f.) $1 \cdot 18 ; \quad P>0.5$

$+\chi^{2}$ (2 d.f.) $6.51 ; P<0.05$

\section{Discussion}

Our experience with vincristine and prednisone confirms the observation of others (Acute Leukaemia Group B, 1965 ; Hananian et al., 1965) that this is an extremely effective drug combination for the induction of remissions in acute lymphoblastic leukaemia, and shows that it is of ten capable of inducing two or more successive remissions in the same patient, though remission rates diminish progressively throughout the course of the disease. A complete remission rate of $100 \%$ in 22 consecutive previously untreated cases compares very favourably with previously reported series, though it is closely comparable to the best of them. In the great majority of these patients complete remissions were achieved within one month.

The chief disadvantage of vincristine is its neurotoxicity, but this is known to be dose-related (Karon et al., 1962; Carbone et al., 1963), and, like Karon et al. (1966), we have been able to show that the therapeutic and neurotoxic effects of the drug can be largely dissociated by confining the dose of the drug to the minimum necessary to induce remission, and by stopping it as soon as remission has been achieved. In practice three or four weekly doses, each of 1.5-2 mg./sq. m., are usually sufficient for the purpose ; persistence beyond this point is progressively more likely to cause neurotoxicity and less likely to induce a complete remission. For reasons of toxicity, of course, adrenocortical steroids should also be withdrawn as soon as a remission has been achieved.

In recent years vincristine and/or prednisone have also been used in the treatment of patients during remission, whether in the course of a cyclical chemotherapy regimen (Australian Cancer Society's Childhood Leukaemia Study Group, 1968 ; Krivit et al., 1968) for so-called "reinduction" in patients during maintenance with other antileukaemic drugs (Acute Leukaemia Group B, unpublished) or as components of intensive combined chemotherapy (Henderson, 1967). A possible theoretical objection to their use in these ways would be the risk of development of resistance, so that patients were deprived of their benefit during subsequent relapses. Unless any of these approaches to treatment are clearly shown to improve the quality and duration of total survival, it may be thought that vincristine and prednisone should be reserved for the treatment of relapses.

We wish to thank the physicians of the Hospital for Sick Children who have allowed us to study and to participate in the management of patients under their care. This work was supported by a grant from the Leukaemia Research Fund.

\section{REFERENCES}

Acute Leukaemia Group B (1965). Fournal of the American Medical Association, 194, 75. Australian Cancer Society's Childhood Leukaemia Study Group (1968).
Lancet, 1, 313 .

Carbone, P. P., Bono, V., Frei, E., and Brindley, C. O. (1963). Blood, 
Evans, A. E., Farber, S., Brunet, S., and Mariano, P. J. (1963). Cancer, 16, 1302 .

Frei, E., et al. (1965). Blood, 26, 642

Haggard, M. E., Fernbach, D. J., Holcom's, T. M., Sutow, W. W., Victti, T. J., and Windmiller, J. (1968). Cancer, 22, 438 .

Hananian, J., Holland, J. F., and Sheehe, P. (1965). Proceedings of the American Association of Cancer Research, 6, 26.

Henderson, E. S. (1967). Cancer Research, 27, 2570.

Heyn, R., Beatty, E. C., Hammond, D., Louis, J., Pierce, M., Murphy, M. L., and Severo, N. (1965). Proceedings of the American Association of Cancer Research, 6, 27.
Howard, J. P. (1967). Cancer Chemotherapy Reports, 51, 465.

Karon, M. R. (1968). Cancer Chemotherapy Reports, 52, 473.

Karon, M. R., Freireich, E. J., and Frei, E. (1962). Pediatrics, 30,

Karon, M. R., et al. (1966). Clinical Pharmacology and Therapeutics, 7, 332. Krivit, W., Brubaker, C., Hartmann, J., Murphy, M. L., Pierce, M., and
Thatcher, G. (1966). Fournal of Pediatrics, 68, 965.

Krivit, W., Brubaker, C., Thatcher, L. G., Pierce, M., Perrin, E., and Hartmann, J. R. (1968). Cancer, 21, 352

Mathé, G., et al. (1967). Lancet, 2, 380.

\title{
Type III Hyperlipoproteinaemia
}

\author{
PETER BORRIE,* M.D., F.R.C.P.
}

British Medical fournal, 1969, 2, 665-667

\begin{abstract}
Cummary : Eighteen patients with type III hyperlipoproteinaemia, diagnosed on the basis of skin lesions, serum lipids, and lipoprotein electrophoresis, have been fully investigated over a period of 15 years. The incidence of coronary artery disease was only slightly increased, and was not increased at all among first-degree relatives. Peripheral occlusive arterial disease was probably more common. An increased incidence of carbohydrate intelerance was found in neither the patients nor their relatives. The effects of treatment on the skin were uniformly good.
\end{abstract}

\section{Introduction}

The clinical features of the various types of xanthomatosis have remained curiously ill-defined over the years. This is partly because the syndrome has presented in and been studied by a number of separate disciplines. Dermatological, cardiac, and metabolic departments have independently studied their own group of patients. Possibly more important than this, however, has been the undue emphasis given to the biochemical and genetic features of the condition, so that it has become little more than a series of lipid levels, a lipoprotein electrophoretic pattern, or a family tree. For instance, Fredrickson et al. (1967) studied the plasma lipids and electrophoretic pattern in 24 cases of type III hyperlipoproteinaemia, but described the individual clinical features in only eight (Fredrickson and Lees, 1966). Even so, this remains the largest series to date.

The present paper describes the clinical and biochemical features in 18 cases of type III hyperlipoproteinaemia observed over a number of years. Cases 1,11 , and 13 were reported in a previous communication (Cases 4, 6, and 5 respectively in Borrie, 1957) as being examples of idiopathic hypercholesterolaemic xanthomatosis associated with triglyceridaemia.

\section{Clinical Features}

The clinical features are summarized in Table I. There were 14 men and 4 women, the ages at onset varying from 24 to 53 . All were referred to hospital on account of their skin lesions, which in every case were the first manifestations of their disease. During the same period of time only eight other cases of primary hyperlipoproteinaemia were seen in the skin depart-

* Physician, Department of Dermatology, St. Bartholomew's Hospital, London E.C.1. ment. The duration of the disease to date varies from 1 to 30 years, four patients having suffered for less than five years, two for from 5 to 10 years, nine from 11 to 20 years, and three for more than 20 years.

\begin{tabular}{|c|c|c|c|c|c|c|c|c|c|c|}
\hline \multirow{2}{*}{$\begin{array}{l}\text { Case } \\
\text { No. }\end{array}$} & \multirow{2}{*}{ Sex } & \multirow{2}{*}{$\begin{array}{c}\text { Age } \\
\text { at } \\
\text { Onset }\end{array}$} & \multirow{2}{*}{$\begin{array}{c}\text { Dura- } \\
\text { tion } \\
\text { (Years) } \\
\text { in } \\
1968\end{array}$} & \multicolumn{4}{|c|}{ Xanthomata } & \multirow{2}{*}{ Arcus } & \multirow{2}{*}{$\begin{array}{l}\text { Dia- } \\
\text { betes }\end{array}$} & \multirow{2}{*}{$\begin{array}{c}\text { Cardio- } \\
\text { vascular } \\
\text { Involvement }\end{array}$} \\
\hline & & & & $\mathrm{E}$ & $\mathbf{P}$ & $\mathrm{T}$ & $\mathrm{TN}$ & & & \\
\hline 1 & $M$ & 40 & 20 & + & + & + & - & + & - & $\begin{array}{l}\text { Cardiac and peri- } \\
\text { pheral arierial }\end{array}$ \\
\hline $\begin{array}{l}2 \\
3\end{array}$ & $\mathrm{~F}$ & 34 & 30 & + & + & + & + & - & - & $\begin{array}{l}\text { pneral arierial } \\
\text { Cardiac }\end{array}$ \\
\hline $\begin{array}{l}3 \\
4\end{array}$ & $\stackrel{F}{M}$ & $\begin{array}{l}53 \\
28\end{array}$ & $\begin{array}{l}1 \\
2\end{array}$ & \pm & $\begin{array}{l}+ \\
+\end{array}$ & $\begin{array}{l}+ \\
+\end{array}$ & - & - & - & - \\
\hline 5 & $M$ & 28 & 19 & - & - & + & - & - & $\overline{-}$ & E \\
\hline 6 & $M$ & 30 & 30 & - & + & + & + & + & + & (E.C.G. not per- \\
\hline 7 & $M$ & 38 & 4 & - & + & + & - & - & - & d) \\
\hline $\begin{array}{l}8 \\
9\end{array}$ & & 2 & 16 & $\overline{-}$ & $\overline{-}$ & + & - & - & - & - \\
\hline 10 & $M$ & 26 & $\begin{array}{l}18 \\
14\end{array}$ & $\bar{t}$ & t & $\begin{array}{lll}+ \\
+\end{array}$ & $\bar{t}$ & $\overline{-}$ & $z$ & - \\
\hline 11 & $M$ & 28 & 21 & + & + & + & - & - & $\overline{-}$ & - \\
\hline & $M$ & 29 & 9 & - & - & + & - & - & - & $\begin{array}{l}\text { Rheumatic heart } \\
\text { disease. }\end{array}$ \\
\hline 13 & $M$ & 41 & 18 & - & + & + & - & - & - & $\begin{array}{l}\text { Peripheral arterial } \\
\text { Cardiac }\end{array}$ \\
\hline 14 & $\mathrm{~F}$ & 5 & 14 & - & + & + & - & - & - & Cardiac \\
\hline 15 & $F$ & 48 & 13 & - & + & + & - & - & - & (E.C.G. not \\
\hline 16 & $M$ & 37 & 12 & - & - & + & - & - & + & performed) \\
\hline $\begin{array}{l}17 \\
18\end{array}$ & $M$ & 37 & 8 & - & + & + & - & - & - & Cardiac \\
\hline & $\mathbf{M}$ & 24 & 4 & - & + & + & & - & - & 一 \\
\hline
\end{tabular}

All types of xanthomata were found, eruptive xanthomata occurring in five patients, plane xanthomata of the palmar aspect of the fingers or hands in 13, and tuberose xanthomat in all. These latter, as well as affecting the more usual sites of the elbows, knees, and buttocks, also involved the fingers and hands in nine cases. The frequent involvement of the fingers and hands was one of the most characteristic features of the series, and the types of lesions are illustrated in Fig. 1. Only three patients had tendon lesions and one (Case 1) had xanthelasma. One patient had a corneal arcus before the age of 45 . One patient (Case 10) had gout, beginning at the age of 39,13 years after the onset of the hyperlipoproteinaemia.

One patient had diabetes mellitus beginning at the age of 46 , nine years after the onset of the hyperlipoproteinaemia. The glucose tolerance test was performed in 13 other cases (see Table IV), in all of which it was normal.

Six patients had cardiovascular disease, and the details are shown in Table II. Case 12 also had rheumatic heart disease at the age of 14 and a successful mitral valvotomy at the age of 27 , but this was not thought to be associated with the hyper- 